\title{
Estimation of protein reserves and the nitrogen content of organs in protein-depleted and repleted cocks*
}

\author{
By JACOBUS P. H. WESSELS AND HANS FISHER \\ Nutrition Laboratories, Department of Animal Sciences, Rutgers, \\ The State University, New Brunswick, New fersey, USA
}

(Received I6 Fune I964-Accepted ro October 1964)

The concept of labile nitrogenous matter in the body which may be mobilized during stress conditions and which has become variously known as protein stores, or reserves, is not new. According to Madden \& Whipple (1940), in 1906 Morawitz demonstrated that, during starvation after severe depletion of plasma proteins through bleeding, plasma proteins were regenerated from what Madden \& Whipple believed to be protein stores. Madden \& Whipple (1940), who reported on a series of plasmaphaeresis experiments with dogs, concluded that plasma proteins formed 'part of a balanced system of body proteins' in which a 'steady state of ebb and flow exists between it [the plasma proteins] and a portion of the cell and tissue body proteins'. Yuile, Lucas, Neubecker, Cochrane \& Whipple (1959) have since demonstrated that the drop in plasma proteins of dogs subjected to plasmaphaeresis was smaller than expected, because extravascular protein-building blocks found their way into the plasma proteins. From this observation one might conclude that extravascular proteins may serve as a source of reserve protein drawn upon for the synthesis of plasma proteins under conditions of stress. Fisher (1954) and Mitchell (1962) critically discuss the possible existence of reserve proteins. Both accept the presence in the body of a protein fraction which is readily katabolized when the animal is placed on a diet devoid of nitrogen or is subjected to certain stress conditions. The study of Longenecker \& Hause (1958) may be interpreted as suggesting that free amino acids may also serve as protein reserves by making good dietary protein inadequacies.

The $\mathrm{N}$ excretion of animals on a protein-free diet generally displays a particular pattern. Initially the rate of excretion is rapid, but it gradually declines and becomes constant at a value usually referred to as the endogenous $\mathrm{N}$ excretion (Folin, 1905). According to Allison \& Wannemacher (1957), the magnitude of reduction in N excretion to this constant value may be considered an estimate of protein reserves.

Shapiro \& Fisher (1962) have reported the partial repletion of body $\mathrm{N}$ stores by non-essential amino acid $\mathrm{N}$ in adult cocks depleted to the endogenous level of $\mathrm{N}$ excretion. The non-essential amino acids were added to the repletion diet which provided the essential amino acids at levels just adequate for maintenance (Leveille \& Fisher, 1958). Shapiro \& Fisher suggested that 'the labile nature of protein reserves

* Paper of the Journal Series, New Jersey Agricultural Experiment Station, Rutgers, The State University of New Jersey. Supported in part by Grants-in-Aid from the National Science Foundation and US Public Health A-4904. 
in conjunction with the dynamic state of certain body proteins permit metabolic shifts (namely de- and transamination) to take place at a rate sufficient to provide those amino acids, peptides or proteins necessary to maintain the protein reserves of the animal'. Apparently the cocks receiving the supplementary non-essential amino acid $\mathrm{N}$ were drawing on the same body $\mathrm{N}$ sources to supplement the ingested nonessential N; they thus became 'repleted' or gained N, as did Madden \& Whipple's (1940) dogs in regenerating plasma proteins. The fact that cocks depleted to their endogenous level of $\mathrm{N}$ excretion did not require essential amino acids for partial repletion suggested a possible new approach to the estimation of the magnitude of protein stores. It was reasoned that the evident lack of requirement for supplementary essential amino acids might indicate that essential amino acids present in a reserve pool were available to supplement the dietary non-essential amino acids and thus allow a certain degree of repletion. The size of this reserve might well be estimated from the body $\mathrm{N}$ losses incurred up to the point at which non-essential amino acid $\mathrm{N}$ no longer will, but balanced proteins would, allow repletion.

The experiments now described were designed to study protein depletion and repletion in adult cocks, with special emphasis on the estimation of the magnitude of their 'protein reserves'. The $\mathrm{N}$ content of various body components was also determined.

\section{EXPERIMENTAL.}

\section{Studies on site of $N$ loss}

The purpose of this study was to examine the $\mathrm{N}$ content of various body components during protein depletion.

Plan. Adult, White Leghorn cocks between 1.5 and 2.5 years old were housed in individual cages. They were given a protein-free diet (for composition see Table I, Wessels \& Fisher, 1965) and their $\mathrm{N}$ excretion was measured continuously.

Table I. Mean values with their standard errors for body-weight and nitrogen excretion of White Leghorn cocks depleted of body $N$ with a protein-free diet

\begin{tabular}{|c|c|c|c|c|c|}
\hline \multirow[b]{2}{*}{$\begin{array}{c}\text { Depletion } \\
\text { period } \\
\text { (days) }\end{array}$} & \multicolumn{3}{|c|}{ Body-weight } & \multirow{2}{*}{$\begin{array}{l}\text { N excreted } \\
\text { during } \\
\text { depletion } \\
\text { period } \\
(\mathrm{mg})\end{array}$} & \multirow[b]{2}{*}{$\begin{array}{l}\text { Percentage } \\
\text { body N loss }\end{array}$} \\
\hline & $\begin{array}{l}\text { Initial } \\
\text { (wet) } \\
\text { (g) }\end{array}$ & $\begin{array}{l}\text { Final } \\
\text { (wet) } \\
\text { (g) }\end{array}$ & $\begin{array}{l}\text { Final } \\
\text { (dry, fat-free) } \\
(\mathrm{g})\end{array}$ & & \\
\hline o & $2503 \pm 104$ & $2503 \pm 104$ & $519 \cdot 7 \pm 14 \cdot 6$ & 0 & 0 \\
\hline 2 & $2657 \pm 60$ & $2593 \pm 67$ & $557^{\circ} 9 \pm 17 \cdot 9$ & $454 \pm 78$ & $0.530 \pm 0.108$ \\
\hline 4 & $2536 \pm 169$ & $2383 \pm 177$ & $496 \cdot 7 \pm 39 \cdot 8$ & $2382 \pm 26 I$ & $2.991 \pm 0.268$ \\
\hline 10 & $2700 \pm 204$ & $2290 \pm 159$ & $500 \cdot 8 \pm 43 \cdot 0$ & $5961 \pm 770$ & $6.670 \pm 0.799$ \\
\hline
\end{tabular}

Groups of four cocks were killed after $0,2,4$ and ro days on the protein-free diet. Body-weights and the amount of $\mathrm{N}$ excreted by the cocks up to the time they were killed appear in Table $\mathrm{I}$. The birds were starved for $\mathrm{I} 8 \mathrm{~h}$ and then killed by cutting the jugular veins in the pharynx. Blood was collected to obtain a measure of total plasma volume.

Analytical procedure. Plasma protein content was determined by the biuret method 
as adapted for use with the AutoAnalyzer (Failing, Buckley \& Zak, I960). Lipid was extracted from weighed, oven-dried, body components by shaking the whole tissue or organ for at least $24 \mathrm{~h}$ in a $2: \mathrm{I}(\mathrm{v} / \mathrm{v})$ mixture of chloroform-methanol. The solvent mixture was removed by filtration and the dried residue weighed. The lipid content was then obtained by difference. The $\mathrm{N}$ content of this lipid-free residue was determined by Kjeldahl digestion, followed by the colorimetric determination on the AutoAnalyzer (Ferrari, 1960) of ammonium ion in the digest with sodium phenate and sodium hypochlorite. The feathers and carcasses remaining after removal of the body components already analysed were dried in a forced-draught oven at $32^{\circ}$ and ground. Lipid was removed as just described and portions of the lipid-free material were then analysed for $\mathrm{N}$, as described for the body components.

\section{Depletion-repletion studies}

Eleven experiments, involving seventy-eight cocks and utilizing nine different $\mathrm{N}$ sources during repletion, were carried out.

Plan. Adult, White Leghorn cocks were used in all experiments. They were housed in individual metabolism cages in a temperature-regulated room $\left(21^{\circ}\right)$. Before the beginning of the experiment they had ad lib. access to the standard i $5 \%$ protein diet used as the stock diet in our laboratory. Its percentage composition was: oatmeal $10 \cdot 0$, maize meal $36 \cdot 5$, wheat middlings $10 \cdot 0$, wheatmeal $10 \cdot 0$, soya-bean meal I $_{5} \circ$, meat meal $5 \cdot 0$, lucerne $3 \cdot 0$, limestone $6 \cdot 3$, trace-mineral mixture $0 \cdot 1$, dicalcium phosphate $\mathrm{I} \cdot 2$, dried maize distillers solubles $2 \cdot 5$, sodium chloride $0 \cdot 4$ and vitamins. Some of the birds had been given an exact amount of $\mathrm{N}$ from a similar but semi-refined diet, which contained soya-bean meal supplemented with methionine as the main $\mathrm{N}$ source, to provide $280 \mathrm{mg} \mathrm{N} / \mathrm{kg}$ body-weight daily for $2-7$ days before the beginning of the experiment. There were no indications that this pretreatment had any effect on subsequent $\mathrm{N}$ losses or repletion.

The animals were depleted to different degrees of body $\mathrm{N}$ loss and were, thereafter, placed on different repletion regimens for a 16 -day repletion period. A complete record of $\mathrm{N}$ intake and excretion was kept for the duration of both the depletion and repletion periods. The manner of depletion was varied so that birds with different losses of body $\mathrm{N}$ could be obtained. The cocks consumed $a d l i b$. a protein-free diet for 6-1o days. Those that were given the protein-free diet for less than ro days were either starved for an additional $4-7$ days or given a maintenance diet which supplied, in the form of free amino acids, an amount of dietary $\mathrm{N}$ equivalent to their endogenous $\mathrm{N}$ excretion ( $150 \mathrm{mg} / \mathrm{kg}$ body-weight daily, Leveille \& Fisher, 1958).

During the I6-day repletion period the cocks were given diets supplying daily $280 \mathrm{mg} \mathrm{N} / \mathrm{kg}$ body-weight, an amount previously shown to be adequate for the maintenance of non-depleted adult cocks (Leveille $\&$ Fisher, 1958) or for the repletion of depleted ones (Shapiro \& Fisher, I962). The $N$ content of a diet containing zein was higher for reasons explained below (see p. 60). When all the $\mathrm{N}$-containing diet had been consumed, a protein-free diet was made available at the rate of $15 \mathrm{~g} / \mathrm{kg}$ bodyweight daily.

During five of the last six trials blood for chemical analysis was drawn from the 
wing veins of the cocks. Predepletion blood samples were obtained from twelve of these cocks and prerepletion samples from an additional seven. All blood was taken immediately before food was offered, i.e. after about $\mathrm{I} 8 \mathrm{~h}$ of fasting.

Twenty-two depleted cocks were killed at the end of the trials.

Diets. The diet used in some instances to maintain cocks at their endogenous level of $\mathrm{N}$ excretion during the depletion period supplied $150 \mathrm{mg} \mathrm{N}$, and all the repletion diets supplied $280 \mathrm{mg} \mathrm{N} / \mathrm{kg}$ body-weight daily. These diets were given at the daily rate of $25 \mathrm{~g} / \mathrm{kg}$ of the body-weight attained by the cocks at the beginning of the depletion or repletion periods respectively. In both types of diet a mixture of essential amino acids provided I $5 \mathrm{mg} \mathrm{N} / \mathrm{kg}$ body-weight daily which was supplemented either with $35 \mathrm{mg} \mathrm{N} / \mathrm{kg}$ body-weight daily (used during the depletion period) provided by a mixture of L-glutamic acid and glycine to give a total of $150 \mathrm{mg} \mathrm{N} / \mathrm{kg}$ body-weight daily, or with various protein and amino acid sources to supply $165 \mathrm{mg}$ or a total of $280 \mathrm{mg} \mathrm{N} / \mathrm{kg}$ body-weight daily for the repletion diets. The compositions of the protein-free diet and of the mixture of essential amino acids which supplied the $115 \mathrm{mg} \mathrm{N} / \mathrm{kg}$ body-weight daily were identical with those described by Shapiro \& Fisher (1962). The following protein sources were used in different repletion diets: egg albumin, $\mathrm{I} 2 \cdot 19 \% \mathrm{~N}$; gelatin, $\mathrm{I} 3.55 \% \mathrm{~N}$; extracted soya-bean protein, $\mathrm{I} 2.4 \mathrm{I} \% \mathrm{~N}$; zein, $13.7 \mathrm{r} \% \mathrm{~N}$; menhaden fish meal, $9.44 \% \mathrm{~N}$. The amino acids and amino acid mixtures studied in repletion diets included: aspartic acid, equal quantities by weight of glycine and glutamic acid, a mixture simulating the amino acid composition of whole-egg protein, and a mixture in which half the $\mathrm{N}$ was supplied by amino acids mixed to simulate whole-egg protein and the other half by equal quantities of glycine and glutamic acid. Since we found (with rats, unpublished results) an apparent digestibility coefficient of $49 \%$ for zein, twice the amount of supplementary zein $\mathrm{N}$ (330 $\mathrm{mg}$ instead of $165 \mathrm{mg} / \mathrm{kg}$ body-weight daily) was included in the repletion diet containing zein.

All diets were provided in pelleted form.

Analytical procedure. The $\mathrm{N}$ content of the diets was determined in the same way as that of the body components (see p. 59). The excreta collected on alternate days were homogenized with water and then analysed for $\mathrm{N}$ in the same way as previously described.

The blood drawn from the wing veins was heparinized and centrifuged in graduated centrifuge tubes and the haematocrit determined from the total blood and packed cell volumes; subsequently total plasma $\mathrm{N}$ was determined in the same manner as for body components and food. Plasma protein content was determined by the procedure already described (see p. $5^{8}$ ), and amino N content was estimated by Danielson's method as described by Hawk, Oser \& Summerson (1954). Plasma creatine plus creatinine levels were determined on plasma obtained at the end of the last two experiments only, by the method of Owen, Iggo, Scandrett \& Stewart (1954), after hydrolysis with 2 parts $\mathrm{N}$-sulphuric acid for $45 \mathrm{~min}$ under $\mathrm{I} 5 \mathrm{lb}$ pressure in an autoclave.

The lipid content of the carcasses was again determined by difference after removal of the lipid with a 2:I (v/v) chloroform-methanol mixture; body $N$ was determined as 
described before. Since our present studies on site of $N$ loss indicated that the liver lost a greater percentage of its $\mathrm{N}$ on depletion than the other body components, certain liver analyses were carried out on the cocks that were killed. Immediately after killing, livers of the cocks were removed and a preliminary homogenate was prepared with ice in a Waring blendor. Nucleic acids (RNA and DNA) were determined on weighed portions of this material, which was finely homogenized with $95 \%$ ethanol in a tissue grinder. The procedure used for the nucleic acid determinations was a modified Schneider method as described by Mendes \& Waterlow (1958). $\mathrm{N}$ analysis of the

Table 2. Mean nitrogen values with their standard errors for body components of groups of four White Leghorn cocks depleted of body $N$ on a protein-free diet

\begin{tabular}{|c|c|c|c|c|}
\hline \multirow[b]{2}{*}{ Measurement } & \multicolumn{4}{|c|}{ Cocks depleted for (days) } \\
\hline & 0 & 2 & 4 & Io \\
\hline \multicolumn{5}{|l|}{ Blood } \\
\hline $\begin{array}{l}\text { Volume } \\
\text { (\% fat- and feather-free } \\
\text { body-weight) }\end{array}$ & $0.224 \pm 0.009$ & $0.248 \pm 0.018$ & $0.232 \pm 0.013$ & $0.197 \pm 0.018$ \\
\hline Haematocrit $(\%)$ & $46 \cdot 6 \pm 2 \cdot 24$ & $41 \cdot 9 \pm 2 \cdot 08$ & $42 \cdot 4 \pm I \cdot 52$ & $44 \cdot 9 \pm 2 \cdot 4 I$ \\
\hline $\begin{array}{l}\text { Plasma proteins: } \\
\text { g/roo ml } \\
\% \text { fat- and feather-free } \\
\text { body-weight }\end{array}$ & $\begin{array}{l}4.564 \pm 0.317 \\
0.547 \pm 0.01 \mathrm{Ix}\end{array}$ & $\begin{array}{l}4.438 \pm 0.393 \\
0.596 \pm 0.042\end{array}$ & $\begin{array}{l}3.324 \pm 0.301 \\
0.422 \pm 0.039\end{array}$ & $\begin{array}{l}4.461 \pm 0.268 \\
0.479 \pm 0.036\end{array}$ \\
\hline \multicolumn{5}{|l|}{$\begin{array}{l}\text { Organs ( } \% \text { fat- and feather- } \\
\text { free body-weight) }\end{array}$} \\
\hline Liver & $0.187 \pm 0.003$ & $0.174 \pm 0.003$ & $0.165 \pm 0.017$ & $0.144 \pm 0.010$ \\
\hline Muscle (m. pectoralis) & $0.535 \pm 0.024$ & $0.531 \pm 0.062$ & $0.521 \pm 0.047$ & $0.460 \pm 0.043$ \\
\hline Spleen & $0.015 \pm 0.001$ & $0.013 \pm 0.002$ & $0.014 \pm 0.001$ & $0.012 \pm 0.002$ \\
\hline Gizzard & $0.161 \pm 0.01 x$ & $0.190 \pm 0.014$ & $0.145 \pm 0.014$ & $0.142 \pm 0.008$ \\
\hline Bone (femur) & $0.104 \pm 0.004$ & $0.099 \pm 0.001$ & $0.098 \pm 0.003$ & $0.095 \pm 0.001$ \\
\hline Heart & $0.051 \pm 0.003$ & 二 & $0.065 \pm 0.003$ & $0.047 \pm 0.005$ \\
\hline $\begin{array}{l}\text { Kidney } \\
\text { Small intestines }\end{array}$ & $\begin{array}{l}0.052 \pm 0.003 \\
0.080 \pm 0.005 *\end{array}$ & $\begin{array}{l}0.052 \pm 0.002 \\
0.090 \pm 0.017^{*}\end{array}$ & $\begin{array}{l}0.056 \pm 0.004 \\
0.081 \pm 0.012\end{array}$ & $\begin{array}{l}0.049 \pm 0.002 \\
0.080 \pm 0.006\end{array}$ \\
\hline Feathers & $3.95 \pm 0.211$ & $3.78 \pm 0.120^{*}$ & $3.58 \pm 0.027^{*}$ & $5.35 \pm 0.306$ \\
\hline $\begin{array}{l}\text { Remainder feather-free } \\
\text { carcass }\end{array}$ & $10.62 \pm 0.19$ & $10.71 \pm 0.31$ & $11.01 \pm 0.15$ & $11 \cdot 06 \pm 0.14$ \\
\hline
\end{tabular}

Values after 2, 4 and Io days of depletion expressed as a percentage of the o-day value Blood

Volume

( $\%$ fat- and feather-free body-weight)

Haematocrit (\%)

Plasma proteins: $\mathrm{g} / \mathrm{I} 00 \mathrm{ml}$

$\%$ fat- and feather-free body-weight
I I I

90

97

109

\begin{tabular}{r}
93 \\
98 \\
90 \\
$\mathbf{1} 8$ \\
95 \\
\hline 100 \\
112 \\
96 \\
101
\end{tabular}

88

96

98

88

Organs ( $\%$ fat- and feather-free body-weight)

Liver

Muscle (m. pectoralis)

Spleen

Gizzard

Bone (femur)

Heart

Kidney

Small intestines

Feathers

Remainder feather-free carcass

* Only three organs were available for analysis. 
liver homogenate was performed by colorimetric analysis on the AutoAnalyzer. Protein content of blood plasma and of liver homogenate, prepared in $10 \mathrm{ml}$ water in a Ten Broeck tissue grinder (available from Arthur H. Thomas Co., Philadelphia, Pa), was determined by the biuret method as described earlier. The amino $\mathrm{N}$ content of liver homogenate was determined by the method previously described for plasma.

\section{RESULTS}

\section{Studies on site of $N$ loss}

In order to avoid a masking effect due to differences in fat content of tissues, the $\mathrm{N}$ values were expressed as a proportion of the fat-free weight of the carcass devoid of feathers.

Haematocrit values dropped during initial depletion but increased again thereafter (after the $4^{\text {th }}$ day). The plasma protein concentration displayed a similar pattern. The drop in blood volume with concurrent concentration of the plasma may explain the upward trend in haematocrit and plasma protein values with continued depletion.

During depletion (Table 2), liver, muscle, spleen and gizzard showed the greatest relative $\mathrm{N}$ loss (expressed as a percentage of fat-free body-weight). When expressed in the same manner as for other organs, the femur showed an early decrease only in $\mathrm{N}$ content. Initially the kidney and heart appeared to lose $\mathrm{N}$ at a slower rate than the rest of the carcass, as evidenced by the higher values observed for the 2- and 4-day depleted cocks.

In agreement with the findings of Summers \& Fisher (1962), our results also showed a significant increase in relative and total feather $\mathrm{N}$ by the end of the depletion period. This increase was due to a marked loss in fat from the feathers.

\section{Depletion-repletion studies}

The correlation between amount of $\mathrm{N}$ lost per kg body-weight and percentage of the lost $\mathrm{N}$ regained on repletion was calculated for those $\mathrm{N}$ supplements with which repletion was carried out from seven or more stages of prior depletion. The resultant correlation coefficients appear on the last line of Table 3. Regression equations were calculated for aspartic acid, gelatin and fish meal as repletion supplements, since for these additives the correlation coefficients were statistically significant and a sufficient number of values was available. The regression equations were:

$$
\begin{array}{lll}
\text { Aspartic acid } & Y=104 \cdot 88-40 \cdot 8 X & (n=22), \\
\text { Gelatin } & Y=146 \cdot 22-45 \cdot 9 X & (n=13), \\
\text { Fish meal } & Y=178 \cdot 11-44 \cdot 8 X & (n=10),
\end{array}
$$

where $Y$ represents repletion as a percentage of the $\mathrm{N}$ depletion loss, $X$ represents the body $\mathrm{N}$ lost during depletion and $n$ refers to the number of animals involved. Fig. I shows the observations plotted about the fitted regression lines. The intercept values ( $\mathrm{N}$ loss) of the regression lines with the zero retention line (Fig. $\mathrm{x}$ ) have been converted from $\mathrm{mg} \mathrm{N}$ loss $/ \mathrm{kg}$ body-weight into a percentage of total body $\mathrm{N}$. For this conversion an average body $\mathrm{N}$ value of $37.3 \mathrm{~g} / \mathrm{kg}$ body-weight, based on carcass analyses of twenty-two depleted cocks, was used. The intercept values as a percentage 
of total body $\mathrm{N}$ were 6.9 and 8.6 for, respectively, aspartic acid and gelatin. An intercept value for fish meal seems unrealistic, since presumably such a good-quality protein would permit repletion from any state of protein depletion.

Table 3. Nitrogen retention expressed as a percentage of $N$ loss of depleted White Leghorn cocks given different dietary $N$ supplements $\uparrow$

\begin{tabular}{|c|c|c|c|c|c|c|c|c|c|}
\hline \multirow{2}{*}{\multicolumn{2}{|c|}{ N loss }} & \multicolumn{2}{|c|}{ Aspartic acid } & \multicolumn{2}{|c|}{$\begin{array}{l}\text { Glutamic acid } \\
\text { plus glycine }\end{array}$} & \multicolumn{2}{|c|}{ Gelatin } & \multicolumn{2}{|c|}{$\begin{array}{c}\text { Isolated } \\
\text { soya protein }\end{array}$} \\
\hline & & \multirow{2}{*}{$\begin{array}{l}\text { No. } \\
\text { of } \\
\text { cocks }\end{array}$} & \multirow{2}{*}{$\begin{array}{c}\mathrm{N} \\
\text { retained } \\
(\%)\end{array}$} & \multirow{2}{*}{$\begin{array}{l}\text { No. } \\
\text { of } \\
\text { cocks }\end{array}$} & \multirow{2}{*}{$\begin{array}{c}\mathrm{N} \\
\text { retained } \\
(\%)\end{array}$} & \multirow{2}{*}{$\begin{array}{l}\text { No. } \\
\text { of } \\
\text { cocks }\end{array}$} & \multirow{2}{*}{$\begin{array}{c}\mathrm{N} \\
\text { retained } \\
(\%)\end{array}$} & \multirow{2}{*}{$\begin{array}{l}\text { No. } \\
\text { of } \\
\text { cocks }\end{array}$} & \multirow{2}{*}{$\begin{array}{c}\mathrm{N} \\
\text { retained } \\
(\%)\end{array}$} \\
\hline $\begin{array}{l}\mathrm{g} / \mathrm{kg} \\
\text { body-wt }\end{array}$ & $\begin{array}{c}\% \text { of } \\
\text { body } \mathrm{N}\end{array}$ & & & & & & & & \\
\hline$<\mathrm{I}_{4} 4$ & $<3.75$ & 3 & $47 \cdot 3$ & I & $40 \cdot 5$ & 4 & 80.7 & - & - \\
\hline$I \cdot 4-I \cdot 7$ & $3 \cdot 8-4 \cdot 6$ & 5 & $5 I \cdot 7$ & 4 & $6 \cdot 2$ & $\mathrm{x}$ & $72 \cdot 9$ & 3 & $70 \cdot 3$ \\
\hline $1 \cdot 7-2 \cdot 0$ & $4 \cdot 6-5 \cdot 4$ & 4 & $3^{8 \cdot 7}$ & - & - & - & - & I & $6_{3} \cdot 1$ \\
\hline $2 \cdot 0-2 \cdot 3$ & $5 \cdot 4-6 \cdot 2$ & 4 & $5^{\cdot 6}$ & $\mathbf{I}$ & 10.6 & 2 & $47 \cdot I$ & - & - \\
\hline $2 \cdot 3-2 \cdot 6$ & $6 \cdot 2-7 \cdot 0$ & 4 & $-8 \cdot 8$ & I & $5 \cdot 1$ & 2 & $45 \cdot 4$ & 2 & $31 \cdot 5$ \\
\hline $2 \cdot 6-2 \cdot 9$ & $7 \cdot 0-7 \cdot 8$ & I & $-7 \cdot 3$ & - & - & I & -10.9 & I & $3 \cdot 3$ \\
\hline $2 \cdot 9-3 \cdot 2$ & $7 \cdot 8-8 \cdot 6$ & I & $17 \cdot 2$ & $\mathbf{I}$ & -0.7 & I & $4 \cdot 8$ & - & - \\
\hline $3 \cdot 2-3 \cdot 5$ & $8 \cdot 6-9 \cdot 4$ & - & - & - & - & 2 & -8.0 & - & - \\
\hline$>3.5$ & $>9.4$ & - & - & - & - & - & - & - & - \\
\hline \multirow{3}{*}{\multicolumn{2}{|c|}{ Correlation coefficients }} & \multicolumn{2}{|c|}{$-0.758 * *$} & \multicolumn{2}{|c|}{-0.486} & \multicolumn{2}{|c|}{$-0.818 * *$} & \multicolumn{2}{|c|}{$-0.837^{*}$} \\
\hline & & \multicolumn{2}{|c|}{ Fish meal } & \multicolumn{2}{|c|}{$\begin{array}{c}\text { Egg-simulated } \\
\text { amino acid } \\
\text { mixture }\end{array}$} & \multicolumn{2}{|c|}{$\begin{array}{l}\text { Diluted egg- } \\
\text { simulated amino } \\
\text { acid mixturef }\end{array}$} & \multicolumn{2}{|c|}{$\begin{array}{l}\text { Albumin } \\
\text { or zein }\end{array}$} \\
\hline & $\overbrace{}^{N}$ loss & $T$ & & & & & & & \\
\hline $\begin{array}{c}\mathrm{g} / \mathrm{kg} \\
\text { body-wt }\end{array}$ & $\begin{array}{c}\% \text { of } \\
\text { body } \mathrm{N}\end{array}$ & $\begin{array}{l}\text { of } \\
\text { cocks }\end{array}$ & $\begin{array}{c}\text { retained } \\
(\%)\end{array}$ & $\begin{array}{l}\text { No. } \\
\text { of } \\
\text { cocks }\end{array}$ & $\begin{array}{l}\text { retained } \\
(\%)\end{array}$ & $\begin{array}{l}\text { No. } \\
\text { of } \\
\text { cocks }\end{array}$ & retained & $\begin{array}{l}\text { No. } \\
\text { of } \\
\text { cocks }\end{array}$ & $\begin{array}{l}\text { retained } \\
(\%)\end{array}$ \\
\hline$<\mathrm{I} \cdot 4$ & $<3.75$ & $\mathbf{I}$ & $\mathrm{I} 35^{-8}$ & - & - & - & - & 2 & $75 \cdot 6 \S$ \\
\hline$I \cdot 4-I \cdot 7$ & $3 \cdot 8-4 \cdot 6$ & I & $109^{\circ} 9$ & $\mathbf{I}$ & $36 \cdot 8$ & - & - & 3 & $64.8 \$$ \\
\hline $1 \cdot 7-2 \cdot 0$ & $4 \cdot 6-5 \cdot 4$ & - & - & 2 & $26 \cdot 9$ & - & - & - & - \\
\hline $2 \cdot 0-2 \cdot 3$ & $5 \cdot 4-6 \cdot 2$ & $\mathbf{r}$ & $66 \cdot 6$ & 3 & $20 \cdot 3$ & 一 & - & - & - \\
\hline $2 \cdot 3-2 \cdot 6$ & $6 \cdot 2-7 \cdot 0$ & 3 & $58 \cdot 5$ & I & $18 \cdot 6$ & - & - & - & - \\
\hline $2 \cdot 6-2 \cdot 9$ & $7 \cdot 0-7 \cdot 8$ & I & 79.4 & $\mathbf{I}$ & $3 \cdot 8$ & - & - & $\mathbf{I}$ & $32 \cdot 9 \|$ \\
\hline $2 \cdot 9-3 \cdot 2$ & $7 \cdot 8-8 \cdot 6$ & 2 & $42 \cdot 6$ & - & - & 2 & $-5 \cdot 4$ & - & - \\
\hline $3 \cdot 2-3 \cdot 5$ & $8 \cdot 6-9 \cdot 4$ & - & - & - & - & I & -6.9 & - & 一 \\
\hline$>3.5$ & $>9.4$ & I & $27 \cdot 0$ & - & - & I & $-I I \cdot 2$ & - & - \\
\hline \multicolumn{2}{|c|}{ Correlation coefficients } & - & or ** & \multicolumn{2}{|c|}{$-0.904 * *$} & & & & \\
\hline
\end{tabular}

* Significant at $P<0.05$; ** significant at $P<0.01$.

+ Added to the repletion diets in the quantities and manner indicated on p. 60 .

$\ddagger$ Half the $\mathbf{N}$ was supplied by an amino acid mixture simulating whole-egg protein and the rest by glutamic acid and glycine.

$\S$ Albumin was used as $\mathrm{N}$ supplement.

I) Zein was used as $\mathrm{N}$ supplement.

Telationship between body $\mathbf{N}$ loss during depletion and percentage retention during repletion.

It is clear from the regression lines of Fig. I and the detailed results presented in Table 3 that the degree of $\mathrm{N}$ repletion during the I6-day periods was linearly influenced by the degree of prior depletion. Severely depleted cocks retained less or failed to retain any $\mathrm{N}$, depending upon the $\mathrm{N}$ supplement, whereas all moderately depleted birds retained $\mathrm{N}$, irrespective of the $\mathrm{N}$ source.

In the comparison of the efficiency of different $\mathrm{N}$ supplements for repletion, the 
results indicate that the proteins usually considered as of good quality were, in allowing $\mathrm{N}$ retention at any given level of $\mathrm{N}$ depletion, on the whole, superior to the nonessential amino acids or the poorer-quality proteins.

Aspartic acid was effective in permitting repletion when the body $N$ loss did not exceed $2.6 \mathrm{~g} / \mathrm{kg}$ body-weight $(6.9 \%)$. Gelatin, even though totally devoid of an essential amino acid (tryptophan), permitted $\mathrm{N}$ retention at body $\mathrm{N}$ depletion up to $3 \cdot 2 \mathrm{~g} / \mathrm{kg}$ body-weight $(8 \cdot 6 \%)$. The high-quality protein (fish meal) permitted excellent repletion over the entire range of $\mathbf{N}$ depletion studied.

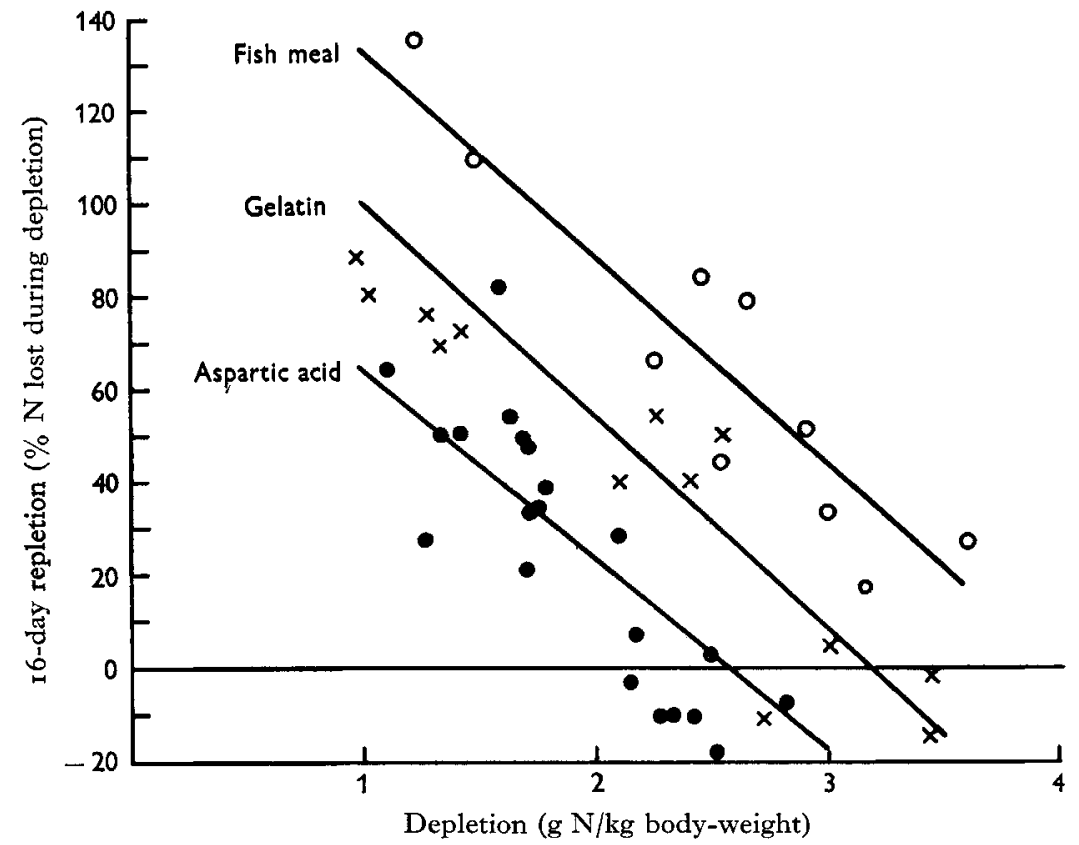

Fig. I. Nitrogen repletion as a function of prior $\mathbf{N}$ depletion in adult cocks fed on a maintenance mixture of amino acids and given aspartic acid, gelatin, or fish meal as the source of supplementary $\mathrm{N}$. $\mathrm{O}$, fish meal $(Y=\mathrm{I} 78 \cdot \mathrm{I}-44 \cdot 8 X ; n=\mathrm{I0}) ; \times$, gelatin ( $Y=146 \cdot 7-45 \cdot 9 X$;

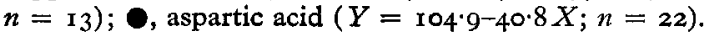

Of the other $\mathbf{N}$ supplements used for repletion, the glutamic acid and glycine mixture was utilized similarly to aspartic acid. A most interesting observation was recorded with the mixture in which half the $\mathrm{N}$ was supplied by amino acids simulating whole-egg protein and half by glycine and glutamic acid. This $\mathrm{N}$ supplement was ineffective in permitting $\mathrm{N}$ retention in cocks depleted to levels similar to those from which some repletion still occurred when gelatin was used as the supplement.

The blood analysis values appear in Table 4. For the depletion phase of the study, values are given in absolute units, whereas the repletion values are presented in terms of correlation coefficients that show the relationship between percentage repletion experienced, and either changes in blood composition during the repletion period or blood composition values recorded at the completion of the I6-day repletion period. During depletion, haematocrit values, total plasma $\mathrm{N}$ and plasma protein concentrations decreased significantly. Upon repletion, only creatine plus creatinine showed 
a significant change (decrease). A comparison, not shown in Table 4, was made between cocks that did and those that did not retain $\mathrm{N}$ on various repletion diets. The former group had significantly less $(P<0.01)$ plasma creatine plus creatinine

Table 4. Blood nitrogen constituents for groups of nine to nineteen White Leghorn cocks before and after protein depletion

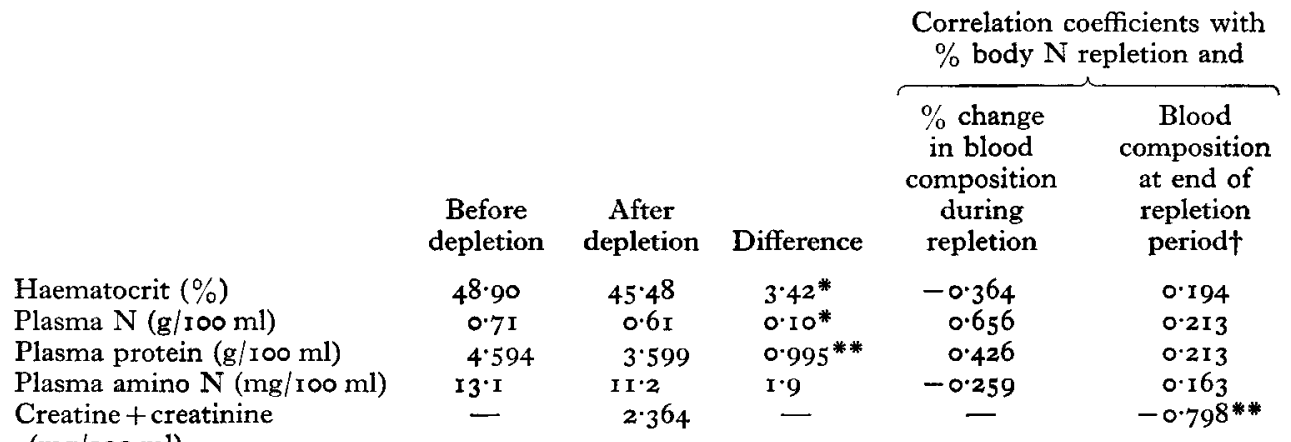

$(\mathrm{mg} / \mathrm{l} 00 \mathrm{ml})$

* Significant at the $5 \%$ test level; ** significant at the $\mathrm{I} \%$ test level.

$\uparrow$ Calculated from forty-nine analyses for plasma $N$, forty-three for plasma proteins, fifty-three for plasma amino $\mathrm{N}$ and twenty-six for creatine plus creatinine.

\section{Table 5. Liver nitrogen components of White Leghorn cocks after protein depletion and repletion}

\begin{tabular}{|c|c|c|c|}
\hline \multirow{2}{*}{ Liver N: } & \multirow[b]{2}{*}{ After depletion $\dagger$} & \multicolumn{2}{|c|}{ After repletion* $†$} \\
\hline & & Effective & Ineffective \\
\hline $\begin{array}{l}\text { As } \% \text { of fat-free body- } \\
\text { weight }\end{array}$ & $0.1233 \pm 0.0093(7)$ & $0.1069 \pm 0.0087(10)$ & $0.1069 \pm 0.0072(7)$ \\
\hline $\begin{array}{l}\text { In relation to liver-DNA } \\
\text { extinction units }\end{array}$ & $3 \cdot 42(2)$ & $3.22 \pm 0.153(10)$ & $2 \cdot 70 \pm 0.243(7)$ \\
\hline $\begin{array}{l}\text { iver proteins: } \\
\text { As } \% \text { of fat-free body- } \\
\text { weight }\end{array}$ & $0.1398 \pm 0.0111(7)$ & $0.1153 \pm 0.0132(10)$ & $0.1081 \pm 0.0088(7)$ \\
\hline $\begin{array}{l}\text { In relation to liver-DNA } \\
\text { extinction units }\end{array}$ & $2 \cdot 96(2)$ & $3.86 \pm 0.62(10)$ & $2 \cdot 78 \pm 0.24(7)$ \\
\hline $\begin{array}{l}\text { Liver amino nitrogen: } \\
\text { As } \% \text { of fat-free body- }\end{array}$ & $0.1073 \pm 0.006 \mathrm{I}(7)$ & $0.0635 \pm 0.0077$ (10) & $0.0656 \pm 0.0078(7)$ \\
\hline $\begin{array}{l}\text { In relation to liver-DNA } \\
\text { extinction units }\end{array}$ & $2 \cdot 04(2)$ & $1.91 \pm 0.17(10)$ & $1 \cdot 62 \pm 0.09(7)$ \\
\hline $\begin{array}{l}\text { Liver RNA (extinction units): } \\
\text { As \% of fat-free body- } \\
\text { weight }\end{array}$ & $\mathrm{I} \cdot 483 \pm 0.198(3)$ & $0.584 \pm 0.042(10)$ & $0.723 \pm 0.058(7)$ \\
\hline In relation to liver-DNA & $I \cdot 34(2)$ & $I \cdot 666 \pm 0.188(10)$ & $1 \cdot 576 \pm 0.242(7)$ \\
\hline
\end{tabular}
extinction units

Values are significantly different $(P<0.05)$ except when they share a common underlining; the 'after depletion' values expressed in relation to liver DNA are excluded from these calculations.

* At the end of the I6-day period during which repletion diets were given; 'Effective' refers to cocks that retained some $\mathrm{N}$ during the repletion period (ten out of seventeen); 'Ineffective' refers to those cocks (seven out of seventeen) that failed to retain $\mathrm{N}$.

+ Means with standard errors; figures in parentheses are the numbers of livers analysed. 
$(20.64 \mu \mathrm{g} / \mathrm{ml})$ than the latter group $(28.69 \mathrm{I} \mu \mathrm{g} / \mathrm{ml})$. Some of the $r$ values, including those for haemotocrit, plasma $\mathrm{N}$, and plasma protein, approached significance at the Io $\%$ level of probability.

Liver composition values are given in Table 5 for cocks killed after depletion or after a period of repletion. The values are presented on the basis of $(a)$ fat-free bodyweight and $(b)$ liver DNA. The DNA values are given as extinction readings. Only ten of the seventeen cocks killed after repletion retained N (column marked 'Effective', Table 5) while seven failed to retain $\mathrm{N}$ (column marked 'Ineffective', Table 5). Of the liver $\mathrm{N}$ components analysed, when expressed as a percentage of fat-free body weight, amino $\mathrm{N}$ and RNA showed a significant decrease whether or not repletion was effective. The liver protein value for the ineffectively repleted cocks, but not that for the effectively repleted ones, was also significantly lower than that for depleted cocks.

When liver $\mathrm{N}$ components were expressed on a DNA basis, the ineffectively repleted cocks tended to display lower values than did the depleted or effectively repleted cocks. This observation suggests a certain degree of recovery on diets permitting $\mathrm{N}$ retention.

\section{DISCUSSION}

\section{Body composition changes during depletion and repletion}

We did not observe in adult cocks the considerable $\mathrm{N}$ loss from the alimentary tract reported by Addis, Poo \& Lew (1936) for adult rats starved for 7 days. The reason for this apparent discrepancy may be explained on the basis of the continued intestinal activity in the cocks associated with the eating of the protein-free diet. This contention is supported by the work of Luck (1936) who showed no intestinal N loss in adult rats on a low-protein diet. Ju \& Nasset (1959), on the other hand, killed rats after 8 days on a protein-free diet and showed a $24 \% \mathrm{~N}$ loss from the small intestines and an equal amount from the stomach. Addis et al. (1936) observed considerable $\mathrm{N}$ loss from liver, heart, and a composite of muscle, skin and skeleton in rats on a proteinfree diet. Dickerson \& McCance ( 1960 ) observed a considerable loss in protein $\mathrm{N}$ from the pectoralis muscle of 27 -week-old cockerels whose diet had been restricted in amount for 15 weeks. With certain exceptions, such as the stability of kidney and heart $\mathrm{N}$ of the adult cocks, our depletion results are in general agreement with those cited. The relatively small extent of liver protein repletion was not unexpected, since for the majority of the animals in this study the degree of repletion was less than twothirds the $\mathrm{N}$ lost during depletion. Since the liver is considered a major site for deposition of 'protein reserves', and since, in absolute terms, most of the depletion $N$ loss occurs in muscle, the liver may be one of the last organs to show the effects of repletion.

In their work with Jamaican infants, Waterlow \& Weisz (1956) reported results that are similar to those observed in the present study. When their infants were recovering from protein malnutrition, they had less liver RNA than upon admission to the hospital. In our study there was only a small increase in RNA during repletion (Table 5). 


\section{Repletion with different $N$ sources}

The presence in the adult animal of amino acid, peptide, or protein pools which may be called upon to complement an intake of dietary non-essential amino acids and thus allow the animal, if not too severely depleted, to retain $\mathrm{N}$ is demonstrated by this study. This corroborates the findings reported earlier by Shapiro \& Fisher (1962). Observations similar to those herein reported for adult cocks have been found also for adult man. Fisher, Brush, Shapiro, Wessels, Berdanier, Griminger \& Sostman (1963) demonstrated a significant $\mathrm{N}$ retention from an imbalanced, high-protein diet, deficient in tryptophan, in male college students who had previously experienced a period of negative $\mathrm{N}$ balance on a low-protein diet inadequate in tryptophan. The subjects did not retain $\mathrm{N}$, when the giving of the imbalanced diet was preceded by a period of $\mathrm{N}$ retention or equilibrium on an adequate, balanced-protein intake.

The greater success of the poor-quality protein (gelatin) compared with that of aspartic acid, in repleting depleted cocks was undoubtedly due to the greater variety of amino acids contributed by this $\mathrm{N}$ source. Thus, cocks given aspartic acid retained $\mathrm{N}$ if the prior depletion loss did not exceed $6.9 \%$ of body $\mathrm{N}$. Gelatin was effective up to a body $\mathrm{N}$ loss of $8.5 \%$. These results also support the suggestion by Mitchell (1962) that the adult subject has a 'particulate' amino acid requirement, allowing for the utilization of individual dietary amino acids even in the complete absence of other essential amino acids from the diet. He contrasts this with the 'aggregate' amino acid requirement typical of the growing animal which must have all needed amino acids present in its diet simultaneously.

The repletion results with the $\mathrm{N}$ supplement in which half, or $83 \mathrm{mg} \mathrm{N} / \mathrm{kg}$ bodyweight daily, was derived from an amino acid mixture simulating the composition of whole-egg protein are particularly noteworthy. This supplement was given to cocks that had lost in excess of $6.9 \%$ body $\mathrm{N}$ (depleted beyond protein reserves). We believe that this supplement proved ineffective because the ratio of essential to non-essential amino acids was far out of line, the importance of which has been emphasized by the thorough studies of Swenseid (1963) (mis-spelling of Swendseid in article quoted).

If we are correct in assuming that the effectiveness of aspartic acid (or glutamic acid plus glycine) in permitting $\mathrm{N}$ repletion is related to the protein reserves of the body, it follows that this study provides a quantitative measure of this reserve pool. From this reasoning the protein reserves may be considered to have been depleted (perhaps of only one essential amino acid) when $2.6 \mathrm{~g} \mathrm{~N} / \mathrm{kg}$ body-weight, or $6.9 \%$ body $\mathrm{N}$, had been lost by the adult cocks.

A protein reserve of $6.9 \%$ of body $\mathrm{N}$ is a higher estimate than that of Madden \& Whipple (1940) which was based on studies of plasma protein regeneration. Two of their dogs regenerated plasma protein to the extent of $7.5^{6} \mathrm{~g}$ and $5^{.14} \mathrm{~g} / \mathrm{kg}$ bodyweight. Assuming that plasma protein contains $16 \% \mathrm{~N}$, this regeneration is equivalent to 1.2 and $0.8 \mathrm{~g} \mathrm{~N} / \mathrm{kg}$ body-weight, or half that estimated in the cocks. This difference, which may be due to the species studied, may also be due to other body proteins besides those of the plasma having been depleted and replaced during repletion in the study of Madden \& Whipple. 
It is interesting that the regression lines for aspartic acid, gelatin and fish meal (Fig. x) relating percentage repletion to percentage body $\mathrm{N}$ loss during depletion had essentially the same slope (were parallel to one another). This observation suggests that the ratios of the $Y$ intercept values may be useful as a measure of the repletion potential of dietary $\mathrm{N}$ sources.

Attention is drawn to the large deviation from expectation by certain cocks during repletion. The $\mathrm{N}$ loss per $\mathrm{kg}$ body-weight of different animals cannot be regarded as an accurate measure for comparing percentage body $\mathrm{N}$ loss. Large differences in body composition (Summers \& Fisher, 1962 ), which prevent an accurate estimate of body $\mathrm{N}$ content, may account for the deviations from expected repletion rates.

\section{SUMMAR Y}

I. Body components of sixteen adult cocks given a protein-free diet for $0,2,4$, or to days were compared with respect to nitrogen content; the livers of twenty-three cocks, seven of which had been similarly protein-depleted for to days and the other sixteen either partly repleted or unable to retain the dietary $\mathrm{N}$ offered, were also compared. Liver lost the greatest percentage of its $\mathrm{N}$ but, in terms of total body $\mathrm{N}$ loss, muscle and probably bone lost most $\mathrm{N}$. The livers from repleted cocks had a higher total $\mathrm{N}$ content than those from cocks that did not retain $\mathrm{N}$ during the repletion period (on a liver DNA basis).

2. Adult White Leghorn cocks (including the twenty-three on which liver analyses were performed) were depleted of different amounts of body $\mathrm{N}$ during I0-13 days, during most of which time they received a protein-free diet. Their depletion was followed by 16 days of repletion with different $\mathrm{N}$ sources added to an amount of essential amino acid $\mathrm{N}$ just sufficient to maintain the cocks' endogenous $\mathrm{N}$ excretion.

3. The greater the degree of body $\mathrm{N}$ depletion, the smaller was the extent of repletion obtained during the $\mathbf{I} 6$-day repletion period with all $\mathrm{N}$ sources. Aspartic acid, as the sole $\mathrm{N}$ supplement, allowed repletion of body $\mathrm{N}$ provided not more than $6.9 \%$ body $\mathrm{N}$ had been lost. Other $\mathrm{N}$ sources, including gelatin and especially fish meal, were effective in repleting more severely depleted birds.

4. The effectiveness of aspartic acid to replete body $\mathrm{N}$ losses is discussed in terms of labile $\mathrm{N}$ components and protein reserves of the body. The amount of body $\mathrm{N}$ loss beyond which repletion did not occur with a non-essential amino acid supplement was regarded as a measure of the size of the protein reserve pool.

We would like to express our appreciation to Dr Ralph Shapiro for his stimulating discussions and critical review of this manuscript. 


\section{REFERENCES}

Addis, T., Poo, L. J. \& Lew, W. (I936). F. biol. Chem. Ir5, i I I.

Allison, J. B. \& Wannemacher, R. W. Jr. (1957). Amino Acid Malnutrition. New Brunswick, New Jersey: Rutgers University Press.

Dickerson, J. W. T. \& McCance, R. A. (1960). Brit. F. Nutr. 14, 33 I.

Failing, J. F., Buckley, M. W. \& Zak, B. (1960). Amer. F. clin. Path. 33, 83.

Ferrari, A. (1960). Ann. N.Y. Acad. Sci. 87, 792.

Fisher, H., Brush, M. K., Shapiro, R., Wessels, J. P. H., Berdanier, C. D., Griminger, P. \& Sostman, E. R. (1963). F. Nutr. 8r, 230.

Fisher, R. B. (1954). Protein Metabolism. London: Methuen and Co. Ltd.

Folin, O. (1905). Amer. Y. Physiol. 13, I 17.

Hawk, P. B., Oser, B. L. \& Summerson, W. H. (1954). Practical Physiological Chemistry, I3th ed. New York: The Blakiston Co. Inc.

Ju, J. S. \& Nasset, E. S. (1959). F. Nutr. 68, 633.

Leveille, G. A. \& Fisher, H. (1958). F. Nutr. 66, 44I.

Longenecker, J. B. \& Hause, N. L. (1958). Nature, Lond., 182, 1739.

Luck, J. M. (1936). F. biol. Chem. Ix5, 491.

Madden, S. C. \& Whipple, G. H. (1940). Physiol. Rev. 20, I94.

Mendes, C. B. \& Waterlow, J. C. (1958). Brit. F. Nutr. 12, 74.

Mitchell, H. H. (I962). Comparative Nutrition of Man and Domestic Animals. Vol. I. New York and London: Academic Press Inc.

Owen, J. A., Iggo, B., Scandrett, F. J. \& Stewart, C. P. (1954). Biochem. 7. 58, 426.

Shapiro, R. \& Fisher, H. (1962). F. Nutr. 76, 106.

Summers, J. D. \& Fisher, H. (1962). Z. Ernährungsw. 3, 48.

Swenseid, M. E. (1963). In Proceeding of Symposium on Protein Nutrition and Metabolism. Spec. Publ. Ill. agric. Exp. Sta, no, 4, p. 37.

Waterlow, J. C. \& Weisz, T. (1956). F. clin. Invest. 35, 346.

Wessels, J. P. H. \& Fisher, H. (1965). Brit. F. Nutr. 19, 7 I.

Yuile, C. L., Lucas, F. V., Neubecker, R. D., Cochrane, C. G. \& Whipple, G. H. (1959). F. exp. Med. I09, 165 . 